\title{
As descobertas da medicina no século $X^{1}$
}

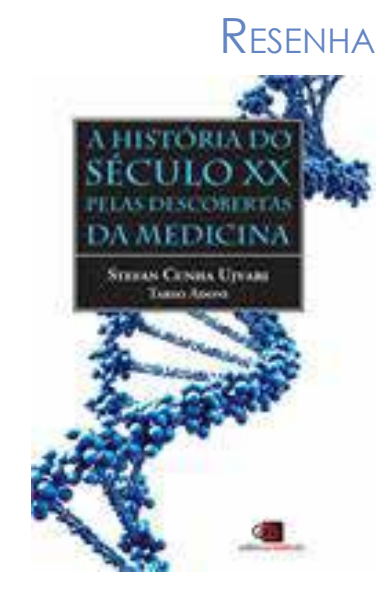

L Carlos Eduardo de Magalhães Barreto

Bacharel em Direito, mestrando no PPGCOM da Universidade Municipal de São Caetano do Sul (in memorian)

Inicia-se o século XX, e, com ele, muitas descobertas médicas que foram fundamentais para a saúde da população. Os autores Stefan Cunha Ujvari e Tarso Adoni, médicos, o primeiro infectologista do Hospital alemão Oswaldo Cruz, autor de diversos livros relacionados à história da infectologia, graduado e pós-graduado pela Escola Paulista de medicina - Universidade Federal de São Paulo e o segundo, neurologista graduado e pós-graduado pela Faculdade de Medicina da Universidade de São Paulo e chefe do serviço de neurologia do Hospital Heliópolis, contam a História do século XX pelas descobertas da medicina. Descrevem, de forma cronológica, em 22 capítulos, os avanços tecnológicos e quanto os médicos e cientistas lançavam mão da criatividade, coragem e raciocínio lógico para viabilizar suas descobertas, muitas vezes com experimentos desumanos e antiéticos aos olhos da ciência atual. Os autores uniram, então, os principais acontecimentos do século com as descobertas médicas e descreveram, no decorrer da história, como esta junção consolidou o alicerce da nossa saúde atual, justificando-se, assim, a resenha em questão.

Este livro originou-se da necessidade dos autores de relatar que por trás de cada descoberta da medicina no século XX existia sempre uma história, nem sempre sem vítimas ou imaculada, mas sempre instigante em relação aos episódios da época. Os autores nos contam, de maneira didática, o avanço industrial da época. O carvão inundava as

1 Ujvari, Stefan Cunha \& Adoni, Tarso. A história do século XX pelas descobertas da medicina. São Paulo: Contexto, 2014. 
fábricas para a produção de aço. Os transatlânticos começaram a substituir os barcos a vela. As viagens passaram a conectar a Europa à América em menos de uma semana. As rotas marítimas e as ferroviárias iniciavam a globalização do planeta, junto à evolução dos cabos telegráficos que encurtavam a distância entre as cidades e alavancavam as negociações comerciais. Explodia, assim, o crescimento urbano e mais de um décimo da população mundial já vivia em cidades. Casas luxuosas dominavam os bairros nobres enquanto os casebres explodiam nos pobres. Os autores nos mostram que, apesar de todo o avanço tecnológico, a vida nas cidades ainda era muito difícil. A medicina ainda não satisfazia as necessidades da população. A mortalidade infantil ainda era muito grande e a expectativa de vida da população estava em torno dos 47 anos de idade.

Os autores nos descrevem que a história da América, muitas vezes, se misturou com a da febre amarela, pois foi grande a corrida europeia por terras americanas economicamente viáveis. Muitas foram as epidemias e as mortes relatadas.

$\mathrm{O}$ primeiro capítulo inicia-se com a primeira grande descoberta do século XX. Ficou comprovado que eram os mosquitos os responsáveis pela transmissão da malária e da febre amarela. Tratou-se de descoberta fundamental para o fim das epidemias urbanas que assolavam cidades europeias, americanas e chinesas. Os capítulos seguintes seguiram os avanços cronológicos das descobertas da medicina, contadas em paralelo aos grandes acontecimentos do século XX.

As vacinas apareceram na década de 1920. As crianças se protegiam contra a tuberculose, difteria, coqueluche e tétano. Anos depois, contra a poliomielite e o sarampo. As epidemias restaram controladas e houve redução na mortalidade infantil. O livro nos mostra que o período foi considerado muito difícil para os cidadãos, devido ao grande número de acidentes com as vacinas e infecções inesperadas. Os primeiros a experimentar as vacinas não suportaram suas versões iniciais e tornaram-se mártires anônimos da evolução da medicina atual.

$\mathrm{Na}$ década de 1930 surgiram os antibióticos. Em setembro e outubro de 1937 foram distribuídos nos Estados Unidos cerca de 200 galões da novidade farmacêutica: “elixir de sulfanilamida". O número de mortes despencou; no entanto, explodiram notícias de experiências desumanas. A cura para a tuberculose veio após a Segunda Guerra Mundial, na década de 1940, depois de muitas vidas ceifadas às custas dos erros e acertos das pesquisas. A Streptomicina destruía a bactéria da tuberculose.

No início dos anos 1950, o autor ilustra, dando enfoque sensacionalista, que a paisagem urbana estava dominada pela fuligem e pelos gases tóxicos gerados pela queima do carvão. A fumaça, misturada à neblina formava o "smog" urbano. Neste cenário, surgiu uma grande epidemia de raquitismo, pois as crianças não absorviam a quantidade 
necessária de cálcio para seu desenvolvimento. Assim, com o desenvolvimento acelerado do mundo e a poluição dos grandes centros, a população ocidental tomou conhecimento do envenenamento maciço que estava sofrendo sem desconfiar. O protagonista era a "fumaça". Os moradores inalavam compostos químicos como carbono, enxofre, metais pesados, cálcio e flúor. O número de internações aumentou muito nas cidades. Os gases desencadearam doenças crônicas e o número de casos de câncer de pulmão aumentou demasiadamente. Descrevem também os autores que as propagandas na mídia incentivavam o consumo exagerado de cigarro, o que também contribuiu em muito para o aumento de diversas patologias na população.

Os avanços da medicina beneficiaram as mulheres na década de 1950 e 1960. Ficou comprovada a utilidade do exame Papanicolau para a detecção do câncer de colo uterino e, posteriormente, veio a descoberta da pílula anticoncepcional, que esbarrou durante muito tempo no preconceito norte-americano contra a contracepção. Os autores nos descreveram também que os hormônios femininos ganharam as luzes dos cientistas. As mulheres podiam enfim escolher entre engravidar ou não e aquelas com dificuldades para engravidar também foram estudadas. Passaram, desta forma, a sobreviver aos partos e a realizar exames preventivos para detecção do câncer. Na década de 1970 surgiu o primeiro "bebê de proveta", após elucidação dos mistérios da ovulação. Foi uma árdua descoberta construída step by step.

Enquanto nos mostram os autores que a industrialização prosperava, elementos radioativos em produtos industrializados matavam crianças pelo consumo da radioatividade. $\mathrm{O}$ chumbo impregnava o cérebro infantil. Estudos mostraram que crianças que tinham elevada concentração de chumbo apresentavam distúrbios de comportamento, déficit de atenção e aprendizado, além de baixos valores de QI. Batalhas foram travadas com empresas intoxicadoras, livrando a humanidade da maior intoxicação de sua história. Por outro lado, a indústria do tabaco lançava até cigarros radioativos, já que encontrava espaços publicitários para promoção do produto, uma vez que, segundo o pensamento da época, cigarros inalados com pitadas de cálcio potencializariam a saúde.

Descrevem os autores que, com o passar dos anos, os malefícios do colesterol foram comprovados. Mostram-nos, assim, de forma primorosa, que desde a década de 1940 acreditava-se que o nível de colesterol fosse abaixo de $280 \mathrm{mg} / \mathrm{dl}$, portanto, bem acima do limite que consideramos normal nos dias de hoje, $200 \mathrm{mg} / \mathrm{dl}$. Desta forma, também nos relatam que muitos infartos ou anginas ocorreram em pessoas com valores entre 200 e $280 \mathrm{mg} / \mathrm{dl}$, índices até então considerados normais. Os médicos passaram a recomendar alimentos pobres em gordura e colesterol e rechaçavam gorduras saturadas. Passou-se, então, a incentivar a manutenção do peso normal e a ingestão de frutas, verduras e grãos, 
e pouco tempo depois foi acrescentada a moderação no consumo de açúcar e sal. A gordura sanguínea foi responsabilizada e considerada a grande vilã do infarto. Após anos e anos de estudo e muitas pesquisas, os autores nos contam sobre o surgimento da estatina, depois do fracasso do triparanol. Contam também que as cirurgias se tornaram seguras com as novas descobertas da época, tendo em vista que entrar no coração era algo impensável no início do século XX. Os médicos não acreditavam nesta possibilidade e pregavam que quem ousasse seccioná-lo ou perfura-lo com lâmina de bisturi estaria fadado ao fracasso.

Os autores descrevem enfaticamente que após um século de buscas a causa da diabetes foi elucidada. Chegou, então, a insulina. Experimentos provaram os efeitos maléficos do tabaco e as transfusões sanguíneas passaram a salvar muitas vidas. A luta contra o câncer se multiplicou e diferentes áreas da ciência se uniram para a melhoria de imagens do corpo humano: radiografia, ultrassonografia, tomografia computadorizada e ressonância nuclear magnética. A expectativa de vida aumentou enquanto as taxas de mortalidade despencaram.

Na década de 1980, uma epidemia de AIDS, apelidada de "peste gay", alavancou o número de mortes na população homossexual, principalmente os jovens. A doença colocou em prova os principais avanços tecnológicos da época, no entanto, os cientistas agiram rapidamente, lançaram novas drogas e definiram esquemas de tratamento e de monitoramento. Surgia então, na década de 1990, o AZT e o coquetel anti-Aids. Vale também destacar que esta doença dizimou parte da população homossexual e aumentou em muito o preconceito. A padronização do tratamento ocorreu no momento certo, pois o vírus já havia se alastrado por todos os continentes, infectando não só os homossexuais masculinos, usuários de drogas injetáveis, hemofílicos e imigrantes haitianos, mas também outros grupos da população não considerados de risco.

Nos anos 2000, foi anunciada a conclusão do projeto Genoma Humano. Iniciavase, desta forma, uma nova era da medicina. Nos dias de hoje, a ciência tem se aprofundado no estudo do DNA, com o objetivo de prever o aparecimento de doenças e câncer, bem como o descobrimento de novas drogas e melhores opções de tratamento das patologias. Podemos chamar de estudo da genética do ser humano. Talvez estejamos testemunhando o nascimento de uma nova era que, no futuro, venha se chamar de o século da genética. A escolha do medicamento ideal para determinado paciente poderá ser realizado de acordo com seu perfil genético, ou, no caso de câncer, pelo padrão de DNA das células normais. Inicia-se, então, uma nova fase da medicina personalizada. Os médicos passarão a tratar "aquela" doença "daquele" paciente e não mais a doença do paciente. O século XXI poderá ser, então, considerado como o século da genética.

$190 \frac{\text { Comunicação \& Inovação, PPGCOM/USCS }}{\text { v. 15, n. } 29(1-11) \text { jul-dez } 2014}$ 